\title{
ANALISIS KESTABILAN MODEL HOST VEKTOR PENYEBARAN DEMAM KUNING PADA POPULASI KONSTAN
}

\author{
A.N. Kenden', R.Ratianingsih², dan J.W. Puspita ${ }^{3}$ \\ 1,2,3 Program Studi Matematika Jurusan Matematika FMIPA Universitas Tadulako \\ Jalan Soekarno-Hatta Km. 09 Tondo, Palu 94118, Indonesia. \\ 1thinaa053@gmail.com, 2ratianingsih@yahoo.com,3juni.wpuspita@yahoo.com
}

\begin{abstract}
Yellow fever is an endemic disease that is transmitted through mosquito vector Aedes aegypti and other species. The disease is found in 32 countries in America and Africa, particularly the countries of the tropical and substropis. Differential equations can be used to represent the spread of yellow fever virus that occurs in the interval $t$ and modeled in the form of a mathematical model. Mathematical models in this study tried to represent the spread of yellow fever based on data obtained and assumptions used. The mathematical model used is a mathematical model consisting of a subpopulation SEIR susceptible (S), Exposed (E), Infected (I), and recovered (R). SEIR mathematical models were then analyzed by looking at the signs of the roots of the characteristic polynomial of the Jacobian matrix evaluated at the critical point. In addition, it can also be done by using the criteria of Routh-Hurwitz to see the behavior of solutions of the system. Analysis of the stability of the system in this study showed that the critical point is free of endemic diseases and the critical point is asymptotically stable. Seir mathematical model simulations show that takes time $t \rightarrow \infty$ to ensure that infected humans free of yellow fever virus infection. This happens because of the yellow fever virus infection that occurs continuously between human and mosquito populations.
\end{abstract}

\section{Keywords $\quad$ : Endemic, Models SEIR, Stability, Simulation Model, Yellow Fever}

\section{ABSTRAK}

Demam kuning merupakan penyakit endemik yang ditularkan melalui vektor nyamuk Aedes aegypti dan spesies lainnya. Penyakit ini terdapat di 32 negara di Amerika dan Afrika, khususnya negara-negara yang beriklim tropis dan substropis. Persamaan diferensial dapat digunakan untuk merepresentasikan penyebaran virus demam kuning yang terjadi dalam selang waktu t dan dimodelkan dalam bentuk model matematika. Model matematika dalam penelitian ini mencoba merepresentasikan tentang penyebaran demam kuning berdasarkan data yang diperoleh dan asumsi yang digunakan. Model matematika yang digunakan adalah model matematika SEIR yang terdiri dari subpopulasi Susceptible (S), Exposed (E), Infected (I), dan Recovered (R). Model matematika SEIR selanjutnya dianalisis dengan cara melihat tanda akar-akar polinomial karakteristik dari matrik Jacobian yang telah dievaluasi pada titik kritis. Selain itu, juga dapat dilakukan dengan cara menggunakan kriteria Routh-Hurwitz untuk melihat perilaku solusi dari sistem. Analisis kestabilan dari sistem dalam penelitian ini menujukkan bahwa 
titik kritis bebas penyakit maupun titik kritis endemik adalah stabil asimtotik. Simulasi model matematika SEIR menunjukkan bahwa memerlukan waktu $t \rightarrow \infty$ untuk memastikan manusia yang terinfeksi terbebas dari infeksi virus demam kuning. Hal ini terjadi karena adanya infeksi virus demam kuning yang terjadi secara terus-menerus antara populasi manusia dan nyamuk.

Kata Kunci $\quad$ : Demam kuning, Endemik, Kestabilan, Model SEIR, Simulasi Model.

\section{PENDAHULUAN}

\subsection{Latar Belakang}

Perubahan iklim yang terjadi sekarang ini diproyeksikan sebagai gejala alam yang bersifat global atau menyeluruh. Pada dasarnya, ada keterkaitan antara perubahan iklim dengan kecepatan penyebaran penyakit, terutama penyakit yang disebarkan oleh vektor nyamuk, misalnya demam kuning (Yellow Fever). Demam kuning adalah penyakit sistemik akut yang disebabkan oleh virus Flavivirus yang ditularkan melalui perantara gigitan nyamuk Aedes aegypti dan spesies lainnya yang ditemukan di daerah tropis dan subtropis di Amerika Selatan dan Afrika (Ryan, 2004).

Berdasarkan data WHO (World Health Organization) pada tahun 2004, ada 200.000 kasus demam kuning, 30.000 diantaranya menyebabkan kematian di seluruh dunia setiap tahun. Meskipun penyakit demam kuning belum pernah dilaporkan di Asia, tetapi wilayah ini tetap beresiko karena adanya faktor pendukung proses transmisi. Pada abad ke XVII dan ke XIX wabah demam kuning dilaporkan di Afrika, Amerika Utara (NewYork, Philadelphia, Charleston, dan New Orleans) dan Eropa (Irlandia,Inggris, Perancis, Italia, Spanyol dan Portugal). Kasus fatalitas meningkat dari $15 \%$ menjadi lebih dari $50 \%$. Sebagian besar kasus dan kematian terjadi di sub-Sahara Afrika disebabkan oleh demam kuning. Hal ini merupakan masalah kesehatan masyarakat yang utama dan terjadi dalam pola epidemi. Tiga puluh dua negara di Afrika sekarang dianggap berisiko demam kuning dengan total populasi 610 juta orang dan lebih dari 219 juta diantaranya tinggal di daerah perkotaan (Murphy, 2003).

Pemodelan matematika menjadi alat pendekatan yang menarik untuk menganalisis tentang penyebaran penyakit menular. Model matematika penyebaran penyakit demam kuning yang dibahas dalam penelitian tugas akhir ini adalah model dinamik dengan model matematika SEIR (Susceptible, Exposed, Infected, dan Recovered). Model SEIR merupakan salah satu model matematika yang menganalisis penyebaran salah satu serotif dari virus Flavivirus antara manusia dengan nyamuk. Model SEIR yang dibentuk berdasarkan asumsi- 
asumsi yang selanjutnya akan ditentukan analisis kualitatif penyebaran demam kuning untuk mengetahui adanya penyebaran penyakit atau tidak adanya penyebaran penyakit melalui analisis kestabilan dari titik kritis bebas penyakit dan titik kritis endemik. Kemudian melakukan simulasi untuk pengecekan hasil analisis agar model lebih representatif terhadap masalah penyebaran penyakit demam kuning.

\subsection{Rumusan Masalah}

Berdasarkan latar belakang diatas, maka dapat dirumuskan beberapa permasalahan sebagai berikut:

1. Bagaimana model penyebaran virus Flavivirus pada penyakit demam kuning pada populasi manusia dan nyamuk?

2. Bagaimana uji kestabilan titik kritis bebas penyakit dan titik kritis endemik dari model penyebaran penyakit demam kuning pada populasi manusia dan nyamuk?

3. Bagaimana simulasi penyebaran virus demam kuning?

\subsection{Tujuan Penelitian}

Berdasarkan rumusan masalah diatas, maka tujuan dari peneliatian ini adalah:

1. Mendapatkan model matematika SEIR dari penyebaran virus Flavivirus pada penyakit demam kuning pada populasi manusia dan nyamuk.

2. Mendapatkan kestabilan titik kritis bebas penyakit dan titik kritis endemik.

3. Mendapatkan hasil simulasi penyebaran virus demam kuning pada daerah kestabilannya.

\subsection{Batasan Masalah}

Penularan antar manusia hanya terjadi melalui perantara vektor nyamuk, artinya penularan secara langsung antar manusia tidak diperhatikan.

\section{METODE PENELITIAN}

\subsection{Studi Pustaka}

Melakukan studi pustaka dengan mengumpulkan materi dari berbagai sumber seperti buku, jurnal dan internet.

\subsection{Tahap Identifikasi}

Tahap identifikasi meliputi penentuan tujuan penelitian, survey pendahuluan, tinjauan pustaka, identifikasi metode analisis serta merumuskan masalah yang akan diteliti. 


\subsection{Mengumpulkan data}

Adapun data yang digunakan dalam penelitian ini adalah data kuantitatif berupa data jumlah penduduk yang diperoleh dari WHO (World Health Organization) dan data mengenai nyamuk demam kuning yang diperoleh dari beberapa buku, artikel, dan jurnal.

\subsection{Teknik Analisa Variabel}

Penelitian ini bersifat kajian kuantitatif terhadap SPD non linear dengan menggunakan linearisasi. SPD yang dikaji dibangun atas variabel-variabel $S_{h h}, E_{h}, I_{h}, R_{h}, S_{v}, E_{v}, I_{v}$, adapun langkah kajian pada setiap kombinasi adalah:

a. Menetukan titik kritis dari SPD dengan meninjau persamaan pembangun pada kondisii stagnan, selanjutnya dievaluasi menggunakan matriks Jacobian.

b. Menganalisis kestabilan sistem dengan cara melihat tanda akar-akar polinomiall karakteristik dari matriks Jacobian yang telah dievaluasi pada titik kritis. Karena polinomial karakteristik dari matriks Jacobian yang diperoleh berderajat tinggi, maka digunakan bantuan kriteria Routh-Hurwitz untuk mempermudahnya.

c. Melakukan simulasi dengan memasukkan nilai-nilai parameter yang telah ditentukan ke dalam SPD.

\subsection{Demam Kuning}

Demam kuning adalah infeksi virus akut yang menyebabkan kerusakan pada saluran hati, ginjal, jantung dan gastrointestinal. Virus ini berupa sebuah virus RNA sebesar 40 hingga $50 \mathrm{~nm}$ dengan indera positif dari genus Flavivirus, dari keluarga Flaviviridae. Virus yang ada di kelenjar ludah nyamuk ditularkan ke manusia melalui gigitan nyamuk betina (nyamuk Aedes aegypti, dan spesies lain). Kemudian virus bereplikasi di dalam tubuh manusia, dan kemudian menginfeksi sel-sel darah putih dan jaringan limfatik. Virus dilepaskan dan bersirkulasi dalam darah. Di tubuh manusia virus memerlukan waktu masa tunas intrinsik 3-5 hari sebelum menimbulkan penyakit. Nyamuk kedua akan menghisap virus yang ada di darah manusia. Kemudian virus bereplikasi di usus dan organ lain yang selanjutnya akan menginfeksi kelenjar ludah nyamuk. Virus bereplikasi dalam kelenjar ludah nyamuk untuk selanjutnya siap-siap ditularkan kembali kepada manusia lainnya. Sekali virus dapat masuk dan berkembangbiak dalam tubuh nyamuk, nyamuk tersebut akan dapat menularkan virus selama hidupnya. Satu-satunya makhluk yang ditunggangi virus ini adalah primata dan beberapa spesies nyamuk. Demam kuning dapat menyebabkan gejala mirip flu, menguning baik dari kulit dan bagian putih mata, yang dapat menyebabkan kematian (Yatim, 2007). 


\subsection{Model Matematika Penyebaran Penyakit Demam Kuning}

Menurut Ma dan Li (2009), kejadian penularan penyakit (epidemi) dapat dimodelkan ke dalam bentuk matematis. Model matematika penyebaran penyakit demam kuning pada penelitian ini adalah model matematika SEIR yang menggambarkan dinamika penyebaran penyakit demam kuning antara populasi manusia dan populasi nyamuk. Penyebaran demam kuning pada populasi manusia dikelompokkan dalam empat subpopulasi yaitu susceptible $\left(S_{h}\right)$, exposed $\left(E_{\hbar_{2}}\right)$, infected $\left(I_{h}\right)$, dan recovered $\left(R_{h_{2}}\right)$. Sedangkan pada populasi nyamuk dikelompokkan dalam tiga subpopulasi yaitu susceptible $\left(S_{V}\right)$, exposed $\left(E_{V}\right)$, dan infected $\left(I_{V}\right)$. Hal ini dikarenakan waktu hidup nyamuk yang singkat sehingga menyebabkan nyamuk terinfeksi virus demam kuning selama hidupnya..

\subsection{Kestabilan Sistem}

Model sistem yang bersifat deterministik sering kali memerlukan pengujian kestabilan, terutama jika model yang bersangkutan akan digunakan untuk keperluan peramalan. Analisis kestabilan sistem adalah kajian atas proses perkembangan suatu sistem yaitu seberapa jauh perkembangan sistem yang dimodelkan menyimpang dari titik keseimbangan yang dicapainya. Sistem keseimbangan yang tak stabil, apabila mengalami gangguan akan semakin menjauhi keadaan seimbang (Tu,1994). Model matematika penyebaran penyakit demam kuning dapat dianalisa kestabilannya dengan melakukan linearisasi sistem yang merepresentasikannya disekitar titik kritis.

\section{HASIL DAN PEMBAHASAN}

\subsection{Hasil}

Penelitian ini merupakan tinjauan matematis terhadap penyebaran penyakit demam kuning pada populasi manusia dan nyamuk yang direpresentasikan ke dalam model SEIR. Model SEIR dibangun berdasarkan asusmsi-asumsi dan kemudian dianalisis untuk mngetahui bagaimana perilaku penyakit demam kuning di masa yang akan datang.

\subsection{Kontruksi Model}

Dalam memodelkan penyebaran penyakit demam kuning pada populasi konstan memperhatikan beberapa asumsi. Diagram transfer untuk penyebaran demam kuning pada populasi manusia dan nyamuk dibuat sebagai berikut: 


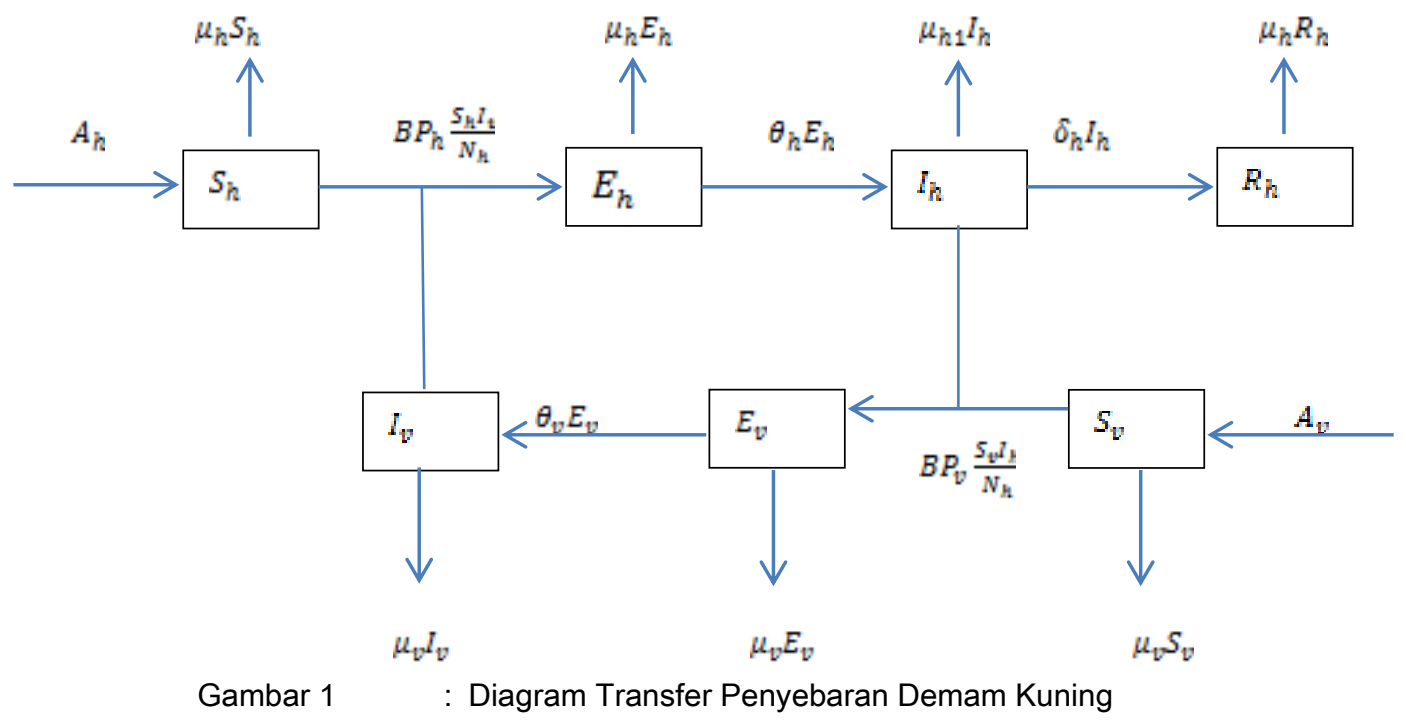

Berdasarkan Gambar 1. model matematika untuk dinamika penyebaran virus demam kuning pada populasi manusia dan nyamuk dapat dituliskan ke dalam sistem persamaan differensial (SPD) sebagai berikut :

$$
\begin{aligned}
& \frac{d S_{h}}{d t}=A_{h}-B P_{h} \frac{S_{h} I_{k}}{N_{h}}-\mu_{h} S_{h} \\
& \frac{d E_{k}}{d t}=B P_{h} \frac{S_{h} I_{k}}{N_{k_{k}}}-\left(\theta_{\hbar}+\mu_{h}\right) E_{h} \\
& \frac{d S_{v}}{d t}=A_{v}-B P_{v} \frac{S_{i} I_{k}}{N_{L_{k}}}-\mu_{v} S_{V} \\
& \frac{d I_{h}}{d t}=\theta_{h} E_{h}-\left(\delta_{h}+\mu_{h 1}\right) I_{h}
\end{aligned}
$$

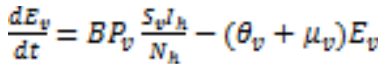

$$
\begin{aligned}
& \frac{a R_{h}}{d t}=\delta_{h} I_{h}-\mu_{h} R_{h} \\
& \frac{\varpi I_{w}}{d t}=\theta_{v} E_{v}-\mu_{v} I_{v}
\end{aligned}
$$

\subsection{Menentukan Titik Kritis}

Sistem persamaan (1) dapat disederhanakan dengan asumsi:

$\frac{B P_{h}}{N_{h}{ }^{2}}=\alpha_{s} S_{h} N_{h}=X_{v} I_{v} N_{h}=Y_{v} \frac{B P_{v}}{N_{h}{ }^{2}}=\beta_{s} S_{v} N_{h}=K_{v} I_{h} N_{h}=L_{v} E_{h} N_{h}=M_{v} R_{h} N_{h}=Q_{v} E_{v} N_{h}=T$

Kemudian substitusikan asumsi diatas ke sistem persamaan (1), sehingga diperoleh:

$$
\begin{aligned}
& \frac{d X}{d t}=A_{h} N_{h}-\alpha X Y-\mu_{h} X \\
& \frac{d M}{d t}=\alpha X Y-\left(\theta_{h}+\mu_{h}\right) M \\
& \frac{d L}{d t}=\theta_{h} M-\left(\delta_{h}+\mu_{h 1}\right) L \\
& \frac{d Q}{d t}=\delta_{h} L-\mu_{h} Q \\
& \frac{d K}{d t}=A_{v} N_{h}-\beta K L-\mu_{v} K \\
& \frac{d T}{d t}=\beta K L-\left(\theta_{v}+\mu_{v}\right) T \\
& \frac{a Y}{d t}=\theta_{v} T-\mu_{v} Y
\end{aligned}
$$


Selanjutnyan sistem persamaan (2) disederhanakan lagi dengan memisalkan $\mu_{\hbar}=a$, $\mu_{v}=b, \theta_{h}+a=c, \delta_{h}+\mu_{h 1}=d$, dan $\theta_{v}+b=e$. Hasil penyederhanaan dapat dituliskan sebagai berikut:

$$
\begin{aligned}
& \frac{d X}{d t}=A_{h} N_{h}-\alpha X Y-a X \\
& \frac{d M}{d t}=\alpha X Y-c M \\
& \frac{d L}{d t}=\theta_{h} M-d L \\
& \frac{d Q}{d t}=\delta_{h} L-a Q \\
& \frac{d K}{d t}=A_{v} N_{h}-\beta K L-b K \\
& \frac{d T}{d t}=\beta K L-e T \\
& \frac{d Y}{d t}=\theta_{v} T-b Y
\end{aligned}
$$

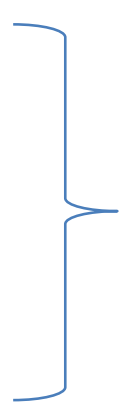

dimana $a, b, c, d$, dan $e$ bernilai positif.

Titik kritis dari sistem persamaan (3) dapat diperoleh dengan meninjau pada keadaan stagnan, yaitu dengan menentukan :

$\frac{d X}{d t}=0, \frac{d M}{d t}=0, \frac{d L}{d t}=0 s \frac{d Q}{d t}=0 x \frac{d K}{d t}=0 s \frac{d T}{d t}=0 s \frac{d Y}{d t}=0$.

Sehingga diperoleh persamaan sebagai berikut:

$$
\begin{aligned}
& A_{h} N_{h}-\alpha X Y-a X=0 \\
& \alpha X Y-c M=0 \\
& \theta_{h} M-d L=0 \\
& \delta_{h} L-a Q=0 \\
& A_{v} N_{h}-\beta K L-b K=0 \\
& \beta K L-e T=0 \\
& \theta_{v} T-b Y=0
\end{aligned}
$$

Sistem persamaan (4) selanjutnya ditentukan titik kritisnya untuk menetukan dua titik kritis, yaitu titik kritis bebas penyakit $\left(T_{1}\right)$ dan titik kritis endemik $\left(T_{2}\right)$.

Titik kritis bebas penyakit deperoleh sebagai berikut:

$T_{1}=\left(\frac{A_{h} N_{h}}{a}, 0,0,0, \frac{A_{v} N_{h}}{b}, 0,0\right)$

sedangkan titik kritis $T_{2}$ diperoleh dengan bantuan softwarre Maple 13 sebagai berikut:

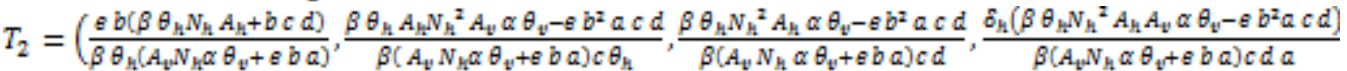

$$
\left.\frac{c d\left(A_{v} N_{h} \alpha \theta_{v}+e b a\right)}{\alpha\left(\beta \theta_{h} A_{h} N_{h}+b c d\right) \theta_{v}} \frac{\beta \theta_{h} N_{h}^{2} A_{h} A_{v} \theta_{v}-e b^{2} a c d}{\left(\beta \theta_{h} N_{h} A_{h}+b c d\right) e \alpha \theta_{v}}, \quad \frac{\beta \theta_{h} N_{h}^{2} A_{h} A_{v} \alpha \theta_{v}-e b^{2} a c d}{\left(\beta \theta_{h} N_{h} A_{h}+b c d\right) b e \alpha}\right)
$$




\subsection{Kestabilan Sistem di Titik Kritis Bebas Penyakit $\left(T_{1}\right)$}

Nilai-nilai eigen persamaan (4) diperoleh dari $\operatorname{det}\left(J_{2}-\lambda I\right)=0$ yaitu:

$\operatorname{det}\left[\begin{array}{ccccccc}-a & 0 & 0 & 0 & 0 & 0 & 0 \\ 0 & -c & 0 & 0 & 0 & 0 & 0 \\ 0 & \theta_{h} & -d & 0 & 0 & 0 & 0 \\ 0 & 0 & \delta_{h} & -a & 0 & 0 & 0 \\ 0 & 0 & 0 & 0 & -b & 0 & 0 \\ 0 & 0 & 0 & 0 & 0 & -e & 0 \\ 0 & 0 & 0 & 0 & 0 & \theta_{b} & -b\end{array}\right]-\left[\begin{array}{ccccccc}\lambda & 0 & 0 & 0 & 0 & 0 & 0 \\ 0 & \lambda & 0 & 0 & 0 & 0 & 0 \\ 0 & 0 & \lambda & 0 & 0 & 0 & 0 \\ 0 & 0 & 0 & \lambda & 0 & 0 & 0 \\ 0 & 0 & 0 & 0 & \lambda & 0 & 0 \\ 0 & 0 & 0 & 0 & 0 & \lambda & 0 \\ 0 & 0 & 0 & 0 & 0 & 0 & \lambda\end{array}\right] \|=$

$\operatorname{det}\left[\begin{array}{ccccccc}-a-\lambda & 0 & 0 & 0 & 0 & 0 & 0 \\ 0 & -c-\lambda & 0 & 0 & 0 & 0 & 0 \\ 0 & \theta_{h} & -d-\lambda & 0 & 0 & 0 & 0 \\ 0 & 0 & \delta_{h} & -a-\lambda & 0 & 0 & 0 \\ 0 & 0 & 0 & 0 & -b-\lambda & 0 & 0 \\ 0 & 0 & 0 & 0 & 0 & -e-\lambda & 0 \\ 0 & 0 & 0 & 0 & 0 & \theta_{V} & -b-\lambda\end{array}\right]=0$

Sehingga dari persamaan (5) diperoleh persamaan karakteristik berderajat 7 sebagai berikut: $(a+\lambda)^{2}(c+\lambda)(d+\lambda)(b+\lambda)^{2}(e+\lambda)=0$

Dari persamaan (6) diperoleh nilai eigen sebagai berikut:

$$
\begin{array}{ll}
(a+\lambda)^{2}=0 & \Rightarrow \lambda_{1}=-a \text { dan } \lambda_{2}=-a \\
c+\lambda=0 & \Rightarrow \lambda_{9}=-c \\
d+\lambda=0 & \Rightarrow \lambda_{4}=-d \\
(b+\lambda)^{2}=0 & \Rightarrow \lambda_{5}=-b \text { dan } \lambda_{6}=-b \\
e+\lambda=0 & \Rightarrow \lambda_{7}=-e
\end{array}
$$

Hasil tersebut memberikan ketujuh nilai eigen yang bernilai negatif sehingga sistem stabil.

\subsection{Kestabilan Sistem di Titik Kritis Endemik $\left(T_{2}\right)$}

Pada persamaan (4) dilakukan transformasi kemudian dievaluasi di titik kritis endemik $(0,0,0,0,0,0,0)$ sehingga diperoleh:

$$
I_{2}=\left[\begin{array}{ccccccc}
-p-a & 0 & 0 & 0 & 0 & 0 & -q \\
p & -c & 0 & 0 & 0 & 0 & q \\
0 & \theta_{h} & -d & 0 & 0 & 0 & 0 \\
0 & 0 & \delta_{h} & -a & 0 & 0 & 0 \\
0 & 0 & -r & 0 & -s-b & 0 & 0 \\
0 & 0 & r & 0 & s & -c & 0 \\
0 & 0 & 0 & 0 & 0 & \theta_{v} & -b
\end{array}\right]
$$

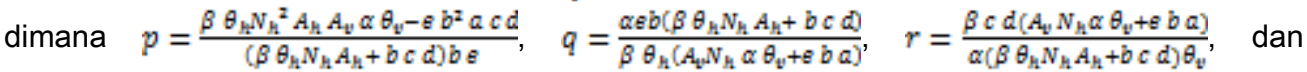
$s=\frac{\beta \theta_{L} N_{h}^{2} A_{h} A_{v} \alpha \theta_{u}-e b^{2} a c d}{\left(A_{\mathrm{u}} N_{h} \alpha \theta_{u}+\varepsilon b a\right) e d}$. Nilai-nilai eigen dari persamaan (7) diperoleh dari $\operatorname{det}\left(J_{2}-\lambda I\right)=0$ yaitu: 


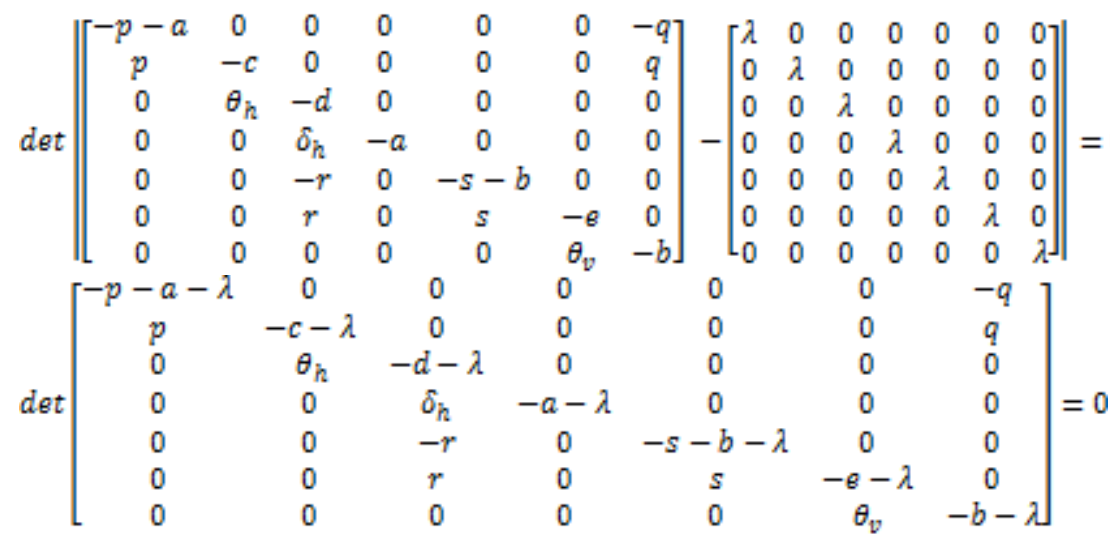

Sehingga dari sistem persamaan (8) diperoleh persamaan karakteristik berderajat 7 sebagaii berikut:

$(-a-\lambda)\left(\lambda^{6}+A \lambda^{5}+B \lambda^{4}+C \lambda^{a}+D \lambda^{2}+E \lambda+F\right)=0$

Dari persamaan (9) untuk persamaan karakteristik berderajat 1diperoleh nilai eigen sebagai berikut: $-a-\lambda=0 \Rightarrow \lambda_{1}=-a$. Hasil tersebut memberikan nilai eigen yang bernilai negatif sehingga kestabilan sistem ditentukan oleh persamaan berderajad 6 dalam $\lambda$ jadi persamaan (9) dapat dituliskan sebagaii berikut:

$\lambda^{6}+A \lambda^{5}+B \lambda^{4}+C \lambda^{3}+D \lambda^{2}+E \lambda+F=0$.

Persamaan (10) dapat dicari kestabilannya dengan menggunakan tabel Routh-Hurwitz sebagaii berikut:

Tabel $1 \quad$ : Tabel Routh-Hurwitz

\begin{tabular}{|l|l|l|l|l|}
\hline$\lambda^{6}$ & 1 & $B$ & $D$ & $F$ \\
\hline$\lambda^{5}$ & $A$ & $C$ & $E$ & 0 \\
\hline$\lambda^{4}$ & $\frac{A B-C}{A}$ & $\frac{A D-E}{A}$ & $F$ & 0 \\
\hline$\lambda^{a}$ & $C-A\left(\frac{A D-E}{A B-C}\right)$ & $E-\frac{A A F}{A B-C}$ & $\frac{-A A D}{A B-C}$ & 0 \\
\hline$\lambda^{2}$ & $\frac{A D-E}{A}-\frac{(A B-C)^{2}+A A D(A B-C)}{A(C-A(A D-E))}$ & $F+\frac{(A B-C) A A D}{A(C-A(A D-E) !}$ & 0 & 0 \\
\hline$\lambda^{1}$ & $E-\frac{A F C}{A B-C}+\frac{C-A(A D-E) L}{(A B-C)^{2} E F}$ & 0 & 0 & 0 \\
\hline$\lambda^{0}$ & $F$ & 0 & 0 & 0 \\
\hline
\end{tabular}


Semua suku pada kolom pertama tabel Routh-Hurwitz harus bertanda positif agar persamaan menjadi stabil, maka haruslah $C>A\left(\frac{A D-E}{A B-C}\right)$ dan $E>\frac{A F C}{A B-C}-\frac{C-A(A D-E) E}{(A B-C)^{2} E F}$ sehinggga persamaan stabil.

\subsection{Simulasi}

Untuk melihat dinamika penyebaran penyakit demam kuning pada populasi nyamuk dan manusia menggunakan model yang telah dikonstruksi, dilakukan simulasi menggunakan software Maple 13 dengan menggunakan nilai-nilai parameter dan nilai awal sebagai berikut: Tabel 2 : Nilai Parameter Komputasi

\begin{tabular}{|l|l|l|l|}
\hline Parameter Komputasi & Nilai (Juta) & Satuan & Sumber \\
\hline$\mu_{h}$ & 0,0045 jiwa & Bulan & H. Purwanto \\
\hline$\mu_{h 1}$ & 0,0025 jiwa & Bulan & H. Purwanto \\
\hline$\mu_{v}$ & 0,02941 jiwa & Bulan & H. Purwanto \\
\hline$\delta_{h}$ & 0,328833 jiwa & Bulan & H. Purwanto \\
\hline$\theta_{h}$ & 0,1667 jiwa & Bulan & H. Purwanto \\
\hline$\theta_{V}$ & 0,1428 jiwa & Bulan & H. Purwanto \\
\hline$B P_{h}$ & 0,75 jiwa & Bulan & H. Purwanto \\
\hline$B P_{V}$ & 0,375 jiwa & Bulan & H. Purwanto \\
\hline
\end{tabular}

Sumber: H. Purwanto (2014)

Tabel 3 : Nilai Awal untuk tiap Subpopulasi

\begin{tabular}{|l|l|l|l|}
\hline Parameter Komputasi & Nilai & Satuan & Sumber \\
\hline$S_{h}(0)$ & 18.250 .000 jiwa & Bulan & WHO \\
\hline$E_{h}(0)$ & $16.666,667$ jiwa & Bulan & WHO \\
\hline$I_{h}(0)$ & 5.000 jiwa & Bulan & WHO \\
\hline$R_{h}(0)$ & 2.500 jiwa & Bulan & WHO \\
\hline$S_{v}(0)$ & 16.109 .250 jiwa & Bulan & H. Purwanto \\
\hline$E_{v}(0)$ & 8.008 .000 jiwa & Bulan & H. Purwanto \\
\hline$I_{v}(0)$ & 743.250 jiwa & Bulan & H. Purwanto \\
\hline
\end{tabular}

Sumber: WHO (2004) dan H.Purwanto (2014)

Dengan menggunakan nilai-nilai parameter dan nilai awal pada tabel (2) dan (3) diperoleh kurva penyebaran demam kuning dalam kurun waktu 150 bulan kedepan masingmasing untuk populasi manusia dan populasi nyamuk pada gambar (2a) - (2d) dan (3a) (3c) sebagai berikut: 


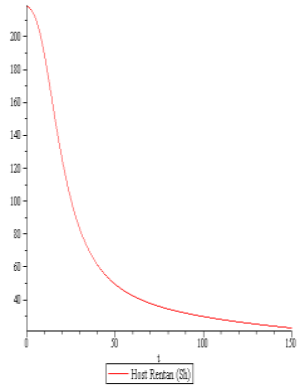

(a)

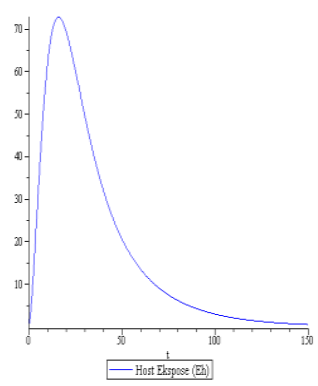

(b)

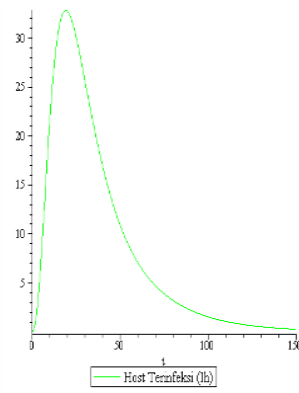

(c)

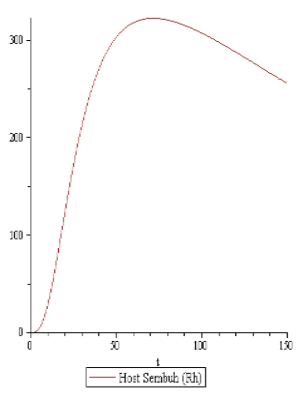

(d)

Gambar 2 : Dinamika Penyebaran Demam Kuning pada Populasi Manusia $0 \leq t \leq 150$

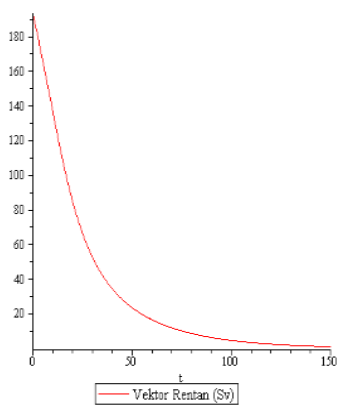

(a)

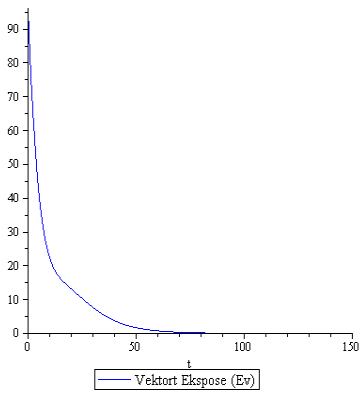

(b)

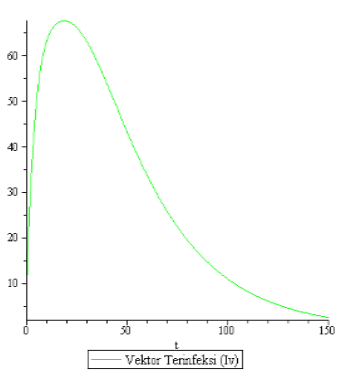

(c)

Gambar 3 : Dinamika Penyebaran Demam Kuning pada Populasi Nyamuk $0 \leq t \leq 150$

\subsection{Pembahasan}

Dari gambar 2(a,b,c,d) dan 3(a,b,c) diatas dapat dilihat bagaimana pnyebaran demam kuning pada populasi manusia dan nyamuk. Dengan nilai awal sebesar 18.250.000 jiwa untuk manusia rentan dan 16.109.250 jiwa untuk nyamuk rentan, terlihat jumlah manusia dan nyamuk yang rentan langsung turun pada bulan ke 1 dan akan stabil pada bulan ke 100 .

Dengan nilai awal sebesar 16.666,667jiwa dan 8.008.000 jiwa untuk manusia dan nyamuk ekspose, 5.000 jiwa dan 743.250 jiwa untuk manusia dan nyamuk terinfeksi, kedua kelompok populasi mengalami peningkatan yang cukup signifikan. Terlihat pada gambar (b) bahwa pada bulan ke 5 sampai bulan ke 20, populasi manusia ekspos mengalami peningkatan dan turun pada bulan ke 25. Sedangkan pada populasi nyamuk ekspos langsung meningkat dari bulan pertama dan akan turun pada bulan ke 10. Terlihat bahwa kenaikan populasi ekspose lebih besar daripada populasi terinfeksi. Hal ini dikarenakan banyaknya populasi rentan yang masuk ke populasi ekspose. Populasi manusia dan nyamuk ekspos mengalami penurunan karena sebagian dari populasi ekspos yang sudah siap untuk mrnginfeksi masuk ke populasi terinfeksi. Pada simulasi terlihat bahwa penyakit akan terus 
ada di dalam kurun waktu lebih dari 100 bulan kedepan. Dalam grafik terlihat bahwa populasi akan menuju ke angka kestabilan pada bulan ke 50.

Dalam penelitian ini, didapatkan hasil bahwa penyakit demam kuning bersifat endemik. Endemik berarti penyakit yang terjadi dengan laju konstan namun cukup tinggi pada suatu populasi. penelitian yang dilakukan terhadap penyebaran penyakit demam kuning dengan menggunakan model epidemik SEIR memberikan hasil bahwa dengan menggunakan model tersebut terlihat bahwa penyakit demam kuning akan menetap dalam kelompok populasi yang diamati.

\section{KESIMPULAN}

\subsection{Kesimpulan}

Berdasarkan hasil dan pembahasan di atas maka diperoleh kesimpulan sebagai berikut:

1. Model matematika penyebaran penyakit demam kuning pada populasi manusia dan nyamuk adalah model matematika SEIR sebagai berikut:

a. Model SEIR pada populasi manusia

$$
\begin{aligned}
& \frac{d S_{h}}{d t}=A_{h}-B P_{h} \frac{S_{h} I_{h}}{N_{h}}-\mu_{h} S_{h} \\
& \frac{d E_{h}}{d t}=B P_{h} \frac{S_{h} I_{h}}{N_{h}}-\left(\theta_{h}+\mu_{h}\right) E_{h} \\
& \frac{d I_{h}}{d t}=\theta_{h} E_{h}-\left(\delta_{h}+\mu_{h 1}\right) I_{h} \\
& \frac{d R_{h}}{d t}=\delta_{h} I_{h}-\mu_{h} R_{h}
\end{aligned}
$$

b. Model SEIR pada populasi nyamuk

$$
\begin{aligned}
& \frac{d S_{V}}{d t}=A_{V}-B P_{V} \frac{S_{u} I_{k}}{N_{L_{k}}}-\mu_{V} S_{V} \\
& \frac{d E_{v}}{d t}=B P_{v} \frac{S_{v} d_{L}}{N_{L_{2}}}-\left(\theta_{v}+\mu_{V}\right) E_{V} \\
& \frac{a I_{v}}{d t}=\theta_{v} E_{v}-\mu_{v} I_{v}
\end{aligned}
$$

2. Kestabilan sistem pada model matematika penyebaran penyakit demam kuning adalah stabil asimtotik yang menunjukkan kasus endemik dan tidak stabil yang menunjukkan kasus nonendemik.

3. Simulasi penyebaran penyakit demam kuning pada suatu model SEIR dalam penelitian ini menunjukkan kasus yang endemik, artinya penyakit demam kuning masih ada dalam populasi manusia dan nyamuk. Namun, untuk memastikan populasi manusia bebas terinfeksi dari virus demam kuning memerlukan waktu $t \rightarrow \infty$. Hal ini 
dikarenakan adanya proses penyebaran virus demam kuning yang secara terus menerus antara kedua populasi tersebut.

\section{DAFTAR PUSTAKA}

[1] Murphy, Jim. 2003. An American Plague: The True and Terrifying Story of the Yellow Fever Epidemic of 1793. New York: Clarion Books.http://www.amazon.com/exec/obidos/ISBN=0395776082. [26 Agustus 2014].

[2] Ma, Z. Dan Li, J. 2009. Dinamical Modeling and Analysis of Epidemics. World Scientific Publishing, Singapore.

[3] Ryan, K,J. 2004. Sherris Medical Microbiology (ed. 4th. http://www.amazon.com/exec/obidos/ISBN=0838585299. [26 Agustus 2014].

[4] Tu, P. N. V. 1994. Dynamical System An introduction with Application in Economics and Biologi, Springer-Verlag, Germany.

[5] Yatim, Faisal. 2007. Macam-Macam Penyakit Menular dan Cara Pencegahannya Jilid 2. Jakarta: Pustaka Obor Populer 2. 